ABORIGINAL HISTORY 1978 2:2

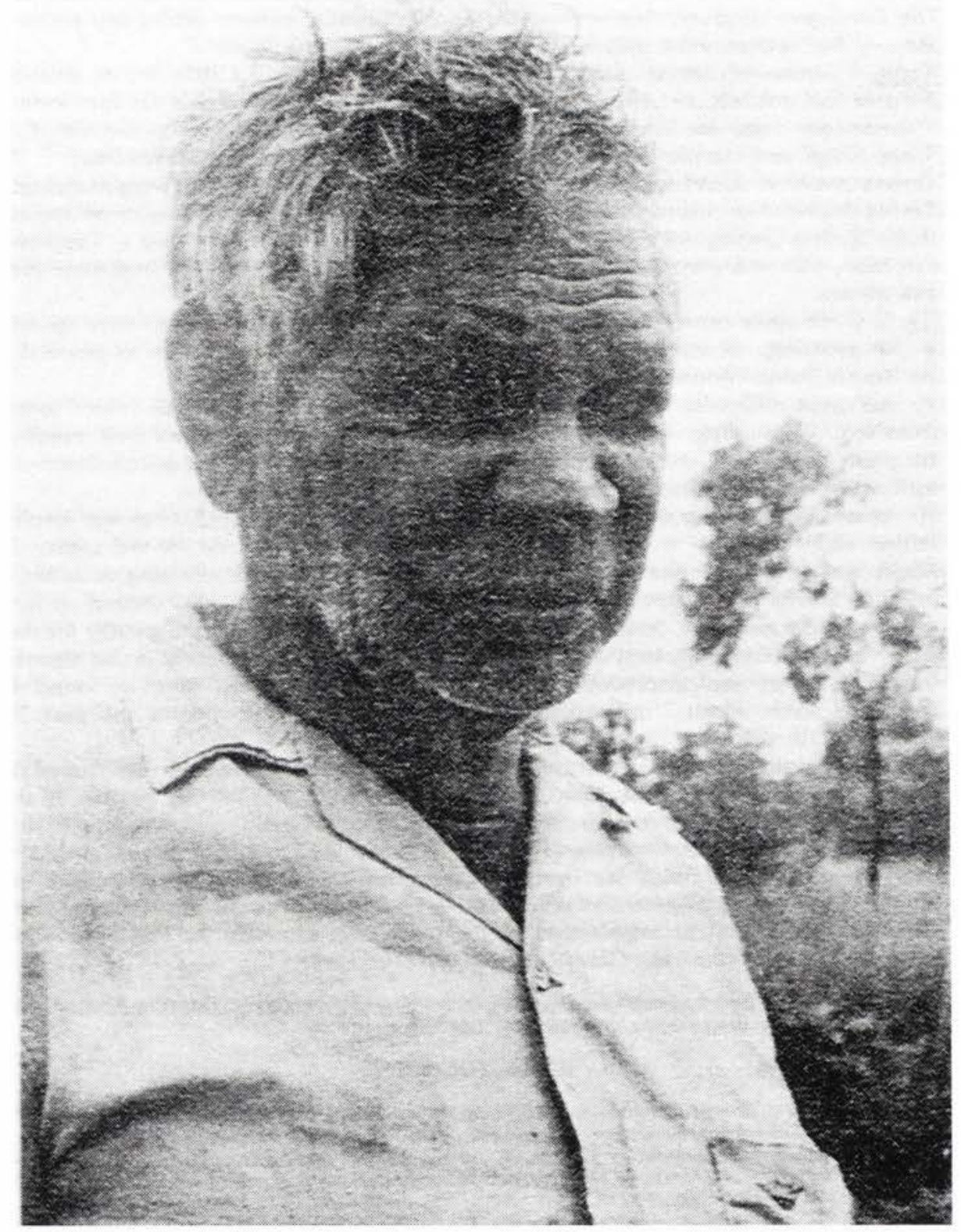

Sandy McDonald

Photograph by Bruce Shaw, 1978. 


\title{
THEY DID IT THEMSELVES: REMINISCENCES OF SEVENTY YEARS
}

\author{
Bruce Shaw and Sandy McDonald
}

\begin{abstract}
Northern Australia today retains many of the anachronistic features of the colonial system, a system which is revealed in numberless ways on the cattle stations, ${ }^{1}$ on missions and government settlements (particularly in north Queensland), and in small country towns both old and new by the attitudes and assumptions of the people living in these differing social environments. In the East Kimberley, one of the latest of Australia's frontiers, these attitudes - of exploitation and racial dominance date back to the early 1880 s. There are people born around the turn of the century who remember vividly the mistreatment received by neighbours and kinfolk, and by themselves, at the hands of the colonizing whites. The experiences of brutality, deviousness, insensitivity and fear are very much part of northern Aboriginal oral traditions, many still lively and dynamic. The resentments generated are passed on not unnaturally from the old to the young and are strengthened, if not exacerbated, by the present social system. Gjessing" notes that: "What is "forgotten" does not disappear, but sinks down to the unconscious level. The events of yesterday and today are already on their way into our tradition', and concerning violence in colonialism he adds, citing Lévi-Strauss, 'a situation of this kind cannot be forgotten, much less erased'. Tradition, for the people that I know in the East Kimberley, remains still at the conscious level.
\end{abstract}

In the last decade many elderly Aborigines have been displaced from East Kimberley cattle stations as a result of the introduction of higher wages for Aboriginal stock workers. The dependants now considered redundant by management have tended to settle on camping reserves adjacent to various Western Australian towns. The new township of Kununurra was founded officially in 1961, on the site of a construction camp opened in 1959. From 1959 to 1963 a diversion dam was under construction at Bandicoord (Bandicoot Bar) on the Ord River a few miles from the townsite. The main irrigation channel and its subsidiaries were also built in these years to service cotton farms established on the black 'cununurra' soil of the Ivanhoe Plain to the north of the town boundary. In 1963 a camping reserve was gazetted by the then Native Welfare Department just within the line of this northern boundary in response to the drift of old people and children - unwanted by the stations - to Kununurra's fringes. Now, some fifteen years later, Kununurra itself has a population somewhat in excess of a thousand persons, including four hundred to six hundred Aborigines of the district. Able-bodied members of the community ply their seasonal occupation as cattle station workers. ${ }^{3}$

In 1973 and 1974 I collected individual histories from about thirty people of Aboriginal descent. These ranged from transcripts of case history size to a handful of life histories. Among the former were the reminiscences of Sandy McDonald, which appear below. They were the result of five interviews, the first in 1970 , three in 1973, and one in 1974. Editing, transforming the narrative from the spoken to the written word, was relatively extensive, but I strove to remain faithful to the original spirit and idiom of the account. The dialectic which predominates in Sandy's anecdotes is woven around his individual conflicts with white authoritarian agencies, specifically the State Aboriginal welfare department and Roman Catholic Christian

1 See Stevens 1974 .

2 Gjessing 1968:400-401.

See Shaw 1974. 
missions, and some of the social issues critical to Aboriginal advancement (education, alcohol dependency, self-help movements). I do not agree with all of Sandy's views. Some of the explanatory notes may modify or illustrate them further from the vantage-point of the present for, since 1974, a number of highly significant changes have taken place, I believe for the better.

Expositions on friendship in the field are among the cliches of anthropological literature, a fashion which is highly suspect to the minds of some writers. ${ }^{4}$ The anthropologist finds his 'key informants' often in the same way that one selects friends and acquaintances, on criteria of affective compatibility. At the same time, one cannot be a friend to all because of differences in motives, temperament and a host of other variables. It is not expected that every person approached by the anthropologist will fall over backwards to talk with him. Some Aboriginal communities, with good reason no doubt, now refuse to permit anthropologists into their midst. As for those who accept the usually sincere approaches of a social scientist to study their way of life (and we cannot rule out the element of fraud in individual cases), there is often created reciprocally a debt of friendship and caring which goes well beyond the mere production of a monograph. This was my experience when collaborating with a Gadjerong man, Grant Ngabidj, now sadly passed away, and Jack Sullivan with whom I am at present working, producing relatively large-scale life histories. The same bonds of friendship can apply however during briefer encounters when collecting case histories. Early in June $1978 \mathrm{I}$ asked Sandy McDonald for his opinion. I pointed out that he had strong dislikes for welfare officers and missionaries and yet in my case as a 'neutral' person he had welcomed me to his camp and discussed his ideas. His response was that he saw no difference between such discussion and friendship. Anthropological field work for these reasons is not to be taken lightly, for friends in the best sense of the word are not found easily.

\section{Reminiscences by Sandy McDonald}

I was born in 1908 on Inverway station in the Northern Territory. My father was a European and he had a ranch, a station called Kirkimby in the Northern Territory. This was on Farqueharson Brothers country and he had permission to live there. He came in the 1880 s as a station manager from Alice Springs. My mother was a fullblood Aboriginal woman, you might as well say Djanu and Nyining, sort of mixed. They spoke the same language and were almost one tribe across. Her father was also Nyining and Djan mixed and I suppose her mother was the same because every Aboriginal was born to speak two languages. From Hall's Creek to Wave Hill you could speak the same language, and Kirkimby station was in that area.

Every Aboriginal language had a boundary, a territory of their own like the border of the Northern Territory and Western Australia, but only a small area. Both sides understood both languages; it was bred into them. They never married across, only at odd times when they shared women with the other side. They do not believe it now; they just marry anyhow, even their blood relations. We found everything going well in those days. My father had no trouble with the Aboriginal people working for him. All of them in the camp followed the Aboriginal rules and customs and went on well, no fighting, no row. All through the World War Two, they were good. They never stole anything. You could leave a truck down the creek, or pack horses, packs and camp rigs and things like that, and grog. They never used to drink grog until after World War Two. Of course, gradually they were getting grog from somebody, and the certificate of citizenship right was granted to them, even to half castes. They were not recognized as an Australian citizen until they bought this ticket for two dollars. This ticket was the so-called Certificate of Citizenship, which was wrongly named.

Willis 1969:141. 
That book should have been named a beer ticket. Aboriginal people were always Australian citizens under the Commonwealth Nationalized and Citizenship Act (sic), but the State government had their own law. They had to buy this book to become an Australian citizen. ${ }^{5}$

In those days the fullblood Aboriginal never got wages, just a shirt, trousers, boots and hat, and a stick of tobacco. That was their payment. And tucker. And any bad boys, say a boy with a bit of intelligence who stuck up for his rights, they would flog him. See, that was going on a long time. The Aborigines got that way that they could not open their mouths out. The station I was on was fairly good. Some of the small stations that started off like it were really good. They relied on the Aborigines to do the work. A lot of those stations now today were built up by Aboriginal people. One squatter taking up a block of land, a pastoral lease, had no labourers except the fullbloods and he had to rely on them, trusting them to muster the cattle and brand them for him. He would go out with them but a lot of times he did not, when he had to go to Hall's Creek or Wyndham or the nearest town in the Territory to get rations or tucker. Everything was trusted to the Aborigines and now today they are condemning them all and saying they are no good. They never give them a go. Way back before the World War Two they gave them a go. There was one station by the name of Ruby Plain, about I suppose approximate distance round by the road sixty miles the other side of Hall's Creek, that was run by one white man and a group of Aborigines, until he sold the station in 1959. He had no trouble with the Aborigines all their life. And all the other stations started off that way.

There were three half caste and two black people in my family. A boy had my mother before my father got hold of her when he was a boundary rider on Ord River station. I had one half-brother and one half-sister, that was all. How that came about of course was the old feller had a lot of natives in his camp and through their custom they gave my mother to him. That was why in those days a lot of the whites did not have any trouble with the fullblood Aborigines. The elders gave them wives, promised them just like in their custom. That was how I was born. My father married my mother and had a bit of a ranch, brought all his cattle onto the block of country then. There was myself and a brother named Duncan who was the youngest. I was the second youngest. Duncan is a broken-down old feller looking older than me according to what people reckon. We went out on the station there for twelve years, then in 1922 the old feller had to sell out and we had to go because we were getting blamed for a lot of things. My father sold the cattle to Vestey's northern agency and bought a mob of horses and we went to Hall's Creek. We had three hundred of them for breeding purposes and to sell down in the Fitzroy area, but the drought came and killed them all. When we came to Western Australia I was about fourteen. I have never been to school but I can read. The old man started to teach me once but he died too soon, in August 1926 at Hall's Creek. He started me off and of course I had to back up myself and things like that. I was about eighteen when that happened

The practice of granting citizenship in this manner was discontinued in 1971. Prior to that year, people of Aboriginal descent living in the Pilbara and the Kimberley divisions were unable to become Australian citizens without first applying to the then Native Welfare Department for that right. The Certificate of Citizenship forms still in use in 1970 bore the date 1961. They required the applicant's full name, date of birth, 'caste' (whether 'half', 'quarter' etc.) parentage, father's and mother's names, 'caste' of both parents, date and place of marriage, 'caste' of spouse, and the names and birth dates of children. In this system with its emphasis upon 'caste' there was a marked tendency to exclude fullblood Aborigines. Successful applicants, designated as 'poor white' by the welfare officer who fllled in the form, were issued with a small cardboard booklet, stamped, signed, not unlike a passport. This was referred to colloquially as a 'dog licence' or 'beer ticket'. Aside from the impertinence of assessing at all whether an applicant was reasonably capable of managing his or her own affairs' (one of the questions to be answered by the public official), the procedure was iniquitous because of the total discretionary power it placed in the hands of the local Native Welfare officer to give or withhold. 
and $I$ had to go and work to keep the tucker bag full, learning to read and write at the same time. I used to do saddling, mostly for drovers, and work as a stockman. In those days we had slate and chalk instead of a lot of books like today. There was no school but everybody used to send away for slates, and we could get little books to write A, B, C and all those things, 'cat' and 'dog'.

I can read papers - I am a bit interested in papers - and sometimes in good books. There was one book called Gone Bush written by a medical officer in the Northern Territory, Sister Kettle. She was employed by the Health Department there and the first job she got was in 1952 when she was sent out to Yuendumu mission settlement north-west of Alice Springs. After a while when she had been working in the hospital out there one of the native women came along and said to her: 'Sister Kettle, my mother is your mother, your mother is my mother. You look after my mother while I'm workin for you'. 'Righto Ruby', she said. And Sister Kettle then turned around and wrote in this book: 'The first job that I got from the Health Department I was sent out to Yuendumu settlement. And the Aboriginal people at Yuendumu settlement accepted me in their midst. They gave me a niche, and accepted me in the tribal custom, in the four marriage structure, and I became a Namaldjeri, the same skin as that woman'. It is the same here, you work off the four. It went on a lot then, and everywhere she went in the Northern Territory she was recognized by the Aboriginal people in certain stations, with her skin name. She had uncles, cousins, nephews, nieces and brothers and sisters no matter where she went. That custom was broken, see, by the early settlers. They forced them to marry women and boys against their religion, against their custom, and through that four marriage structure they kept their tribe in order, for they had no police force, no army, no jail. When they did all that they could not go wrong. In that custom they could not marry their first cousin; it had to be a cousin from another tribe. Through that custom they could not kill anybody, and they stuck to that for nobody knows how long, we can only surmise. Well, if the Aborigines took that custom back you would find they are better off.

Some of these customs should have been accepted in the church. Christianity is doing the Aboriginal no good. The government is trying to introduce changes; they want the Aborigines to take their culture and their customs back. That is the only way. But there are too many missionaries preaching all the time. They say yes, but in their heart they do not say it, you see. I have read it in the paper many a time that that is why the government wants the Aboriginal people to learn their language, so they will understand each other. A white man or woman who is born on the station would tell you the difference. I do not believe Christianity; I will not have it. There is no God in my religion. In Aboriginal custom there was no hell or heaven, there was no such thing as a God. It was nearly the same everywhere; all the tribes had that, among these people and in my own country, although it is a different language here that $I$ do not understand.

After I had been living around Hall's Creek with the horses, I went with an old prospector across to Alice Springs, three years in the desert. We had no trouble with the Aborigines out there. They showed us water and helped us in every way. Of

6 Sandy's paraphrasing is relatively accurate; Kettle (1967:1) says:

"The Wailbri folk of the "Centre", having accepted me as their friend, found a niche for me in their tribal social structure. I became Nabaldjari, and belonged to one of the eight skin-groupings. This privilege, which had disadvantages as well as advantages, provided me with many tribal mothers, fathers and siblings, not to mention uncles, aunts and cousins. News of my acceptance was brought by one of the hospital staff, Ruby Nabaldjari, who explained that I had become her sister, and from then on I was referred to by all as Nabaldjari. The disadvantages of a newly-acquired family were borne home when I remonstrated with my staff over their reluctance to care for a certain elderly woman patient; they blithely pointed out that, since the woman was my mother, it was my duty to care for her'. 
course I learnt nothing, never saw a paper. In those days you could not get newspapers like you do today. We would go into some of the nearest stations round that area, say every three or four months, till we rounded up and went back to Hall's Creek. There was no civilisation whatsoever. This old feller I was with, a white man, could not read or write and I had to read all the miner's rights and a lot of other things to him. He had a diary and I read all that. And the longer I stayed out there I got tired of him and so I never learnt any more after that. You know how a man gets that way that he gets full of some of those old settlers, like the old prospector I was working for, you start arguing the point over something. I had nothing to read then, not even a diary, and I forgot a lot of it.

I never went through the Aboriginal Law. They would not interfere with half caste kids. They would say: 'No, we can't touchim. E's gone to the white man. We leavim out'. In those days too the white men on the stations did not treat half castes too well, although they treated me a little differently from fullbloods. At the same time, when you had a row with them they ran for the rifle. I nearly got shot one time by the man I was working for, but of course when he picked up his rifle I picked up mine. Mostly half caste people were carrying guns, not the fulliblood Aborigines. I said to him: 'What are you going to do with that? You better put it down', and when he saw me with one he put his away. I said: 'Never you do that'. See, I always had something in my swag like that and from that time I never worked on a station without a pistol in my shirt. I learnt that lesson. A few of us carried pistols. I had a gun all my life, and a pistol too.

I was about twenty or twenty-one when I came back to Hall's Creek. I went out again working on the stations; got a job there with an old teamster on a donkey team. I used to take any kind of contracting job and liked the work. I did not like stock work because it was a risky job for little money, £2.0.3 per week. Some stations would pay a little more but not much. In the Territory you received $£ 2.8 .0$. There was one European on the donkey team and we had about four fullblood Aborigines. I was put on as cook. After I finished there I got a job at Mount Amhurst station about sixty miles from Hall's Creek. I went down there to break in some young colts and when I had finished they kept me on until Christmas time. So I came back, and the second year they wanted me there and I returned and worked for them again, leaving once more somewhere around October or November and coming back to Hall's Creek. I looked for gold but could not find any, and spent all my money on tucker. The gold rushes were earlier in $1884-86$. So I had to camp there; I could not go anywhere. There was an old bloke who used to be working round there for the local road board years ago, and he took a block of land out from Hall's Creek. He said to me: 'You come with me, I'll give you a job'. So I went with him and helped him brand up what he could get around his country. Then he said: 'I'll sell you bullock, an you start butcherin in Hall's Creek'. 'Right', I said, and I bought all the bullocks that he had. He was another European starting a ranch you see. This was in 1931.

And I went on butchering and was doing all right. Meat that time was sixpence a pound, not a lot even in those days. I went on killing and we got on together well until the year after in 1932 when I was still butchering. The Native Protector managing Moola Bulla station did not like me butchering. He thought I was killing his bullocks. He came in and never said any thing except to give me a sour look. But he asked the old bloke I was working for: 'Who's the butcher here?' 'Sandy McDonald'. He came round to me and said; 'Where you getting your bullocks from?' I said: 'You mind your own business. I don't ask you any questions'.

Then I left and in 1940 I got a job for a drover and went as far as Newcastle Waters in the Northern Territory, near the highway a few miles from a town called Elliot. I came back from there to Wave Hill and me and another feller started back to Hall's Creek where we did a bit of work for the local road board, but mostly I was 
working for contractors. This was just before the World War, in 1942 or ' 41 . I did a bit of saddling in one particular station out from Hall's Creek and I was a caretaker as well when the manager Jack Skeehan was away droving. He happened to be half caste too, the father of the Skeehans who live here. He died in Derby from heart trouble, so I got a job for fourteen months on Lissadell station, pumping. The windmill man there had to go because he could not get on with the manager, so the manager came and fixed me up to take the windmill job on. All through that there was a bit of a drought and I had to pump all the time, sometimes staying out there by myself and fixing up the engine.

In 1942-43 I was a butcher again, for two years, doing it for another man while he was out droving. In those days there was a Native Protector. They have changed it now to welfare; it was similar to welfare. In those days they called them Native Protector, but they should have called them native enemy, not protector. They were local men. One had the job, then he died or retired and another local man took over and he was worse. He had no time for those fullblood Aborigines and he had a row with them a couple of times. You know, if you had a smart sort of fullblood Aboriginal, a stockman or something like that, he would take him off you. He might want him on the station. He did not want you to have any good stock boys. I had one from the Territory and when we went to Hall's Creek he tried to claim him: 'I want that boy'. 'He's not mine', said the contractor, 'I got nothin to do with the boy. See Sandy. E come here with Sandy'. 'Oh well', he said, 'What I say is law. E got to stay here'. So we finished building the yard. My boss the contractor never told me and when I came past Moola Bulla he was ahead of me, going back to his station out from Hall's Creek. 'Oh', he said, 'Did you call in an get your pay?' I said: 'No'. He said: 'I left it in Moola Bulla'. I said: 'You ad no right to leave it there, sittin there'. 'Why I left it there', he said, he wanted to get that boy you got'. It was funny he did not see me and ask me about the boy. So I called the boy up and I said: I'm goin back to Moola Bulla this momin'. 'Righto', he said. I added: 'Alf George wants you back at Moola Bulla'. He was the Protector that time. 'He wants you back there. If you don't go e's goin to tie you up an put you on a chain an give you a bashin. Now what you gonna do?' He said: 'I'm not going back there. I don't want to go there'. 'Righto, that's enough'. I said to the contractor: 'You hear that, hear what the boy said? When you get out there you tell Alf George to come in an see me in Hall's Creek, an tellim that this boy do not want to go there. An what's more, tellim that e cannot force this boy against his will'. 'Oh', he said, 'righto'.

Of course when I went to town and camped down I saw the constable in charge at Hall's Creek. 'Righto Sandy', he said, 'tell me your trouble'. 'Oh', I said, 'Alf George wanted this boy an this boy doesn't want to go back there, an e's never asked me an e's never asked the boy. He want the boy to go there an e told Ernie Bridge the contractor that $e$ ad every right $e$ said to take any boy off anybody an givem a floggin'. 'Yes', the policeman said, 'I know all about that, givin boys a floggin. They stick to me an now under my care, an they not goin back to Moola Bulla. You camp down there for a few days', he added, 'When e come there just send the boy up to me. I'll fixim.' 'Righto', I said. He said: 'Don't you letim put it over you Sandy. You come to me. I'm after that feller'. Anyway, I pulled up at the old post office straight opposite the two double doors which were open and there he was leaning over the counter for his mail. I went in for mail too. At that time I happened to be working for another contractor, a water borer building a tank, and he asked me to get his mail too. The feller rushed out of the post office and said: 'You're the bastard that's spoilin all the Aborigines. You had no right to take that boy back like that'. And I said: 'Wait a bloody minute. You the bastard that's spoilin on the Aborigines, an puttin them on the chain an floggin em, bashin em. An that's why there's six Aborigines here under police care, in charge a the police until the Prime Minister for the North, Cobbly, comin up. There's six boys in the camp now and you tryin to force 


\section{THEY DID IT THEMSELVES}

this boy against his will'. 'I'll fix you too', he said. 'An that'll be the day you fix me', I said. 'I'll put you on a chain an I'll give you a lashin up', he said. 'You know what'll happen to you', I said, 'Long enough for me to put a cartridge in the breech of this rifle ere. An that's ow long you gonna last. You flog me an see how far you'll go'. 'No, no', he said, 'We don't want to have any row'. 'Well shut up an say nothin about it', I said. The postmaster put his head through the window and listened. 'What did he say to you Sandy?' he asked. 'Oh e tryin to stand over me. You heard what $e$ said to me. E called me a bastard an things like that. Wanted to flog me'. 'Mm', he said, 'That's bad, I eard im, eard what e said. He had no right to say that to you. I'm glad you stood on your dignity'. That was not the second time I had a row with him; it was the third. After showing him my thirty-two rifle he went away and never said any more.

The next time I saw him I had stopped for a smoko with a new boy about four years old. That was Allen, the big feller here who was only a little boy then, a poddy with no mother, like they call a poddy calf. I reared him onto milk after my first wife died in 1941. Allen wanted a feed so I pulled up and boiled a billy to have a cup of tea while he was eating his breakfast. It was about nine o'clock, and that feller pulled up and said: 'Ow are you? You broken down?' 'No', I said. 'Any help?' he said, 'You want any help? I'll give you all the help you want'. 'No thanks Mr George. I'm quite all right', I said, 'I'm not broken down.' 'Oh', he said, 'Well don't be frightened to pull me up any time I come in if you're broken down'. 'Righto', I said, Thanks for your offer'. And the second time I went out near the same place but half a mile apart I pulled up again. And the third time when he came in and saw me doing the same thing: 'You always pull up and make a fire like that?' he asked. 'Yeah, when the kid want a feed. When I eat in the mornin I givim what $e$ want, an I have my cup a tea too'. Mm?', he said, 'That boy here, where's the mother?' I said, Mother died long time'. I met my first wife at Hall's Creek. I think she was a partAboriginal but not by a European, by a half-Maori I think. We had only that one child.

That feller Mr George did not have the grudge against me all the time, only sometimes when he got wild and on the spur of the moment. If you did not pull him up well he would go a bit further with it. He was the only man who said that to me because he was a Protector and he was trying to bounce me around. But I said: 'Don't try to stand over me Mr George. I'ra not like those Aborigines you've got over there. I always have something in my swag. I was not dragged up; I was brought up'. After that he was pretty good, could not do enough for me. However, soon after that, he started bringing in meat to the hospital and the town, giving it to them so I could not sell mine. I reported him to the Minister of the North who came up, and he said to me: Moola Bulla station, that's what they grow meat there for, to sell meat. But he cannot sell meat by the pound. He can sell meat by the quarter or a bullock or half a bullock. We can't stopim on that. But we stoppinim on sellin the meat by pound. He cannot do that'. I was selling it by the pound, which was the normal way.

When I was working for the Main Roads Department from ' 43 to " 45 , driving a truck, we were camped about twelve miles from Sturt Creek. I would go out and get a killer at the station, and I came back once with the calves on the back of the truck. We put them on the table and I helped the cook cut them up, salt them, and put them in the freezer. And one of the blokes who had not been long up in the Kimberleys, had come up from Perth with a truck, asked me: 'Where's you go today Sandy?' I said: 'I went to Mistake Creek'. 'What's Mistake Creek, what is it?'. 'A station', I said. 'How's it come to get the name Mistake Creek?'. I said: I couldn't tell you'. That went on for a few years and I found out after. How I found out was I came back to my camp and started thinking about it. There were two Mistake Creeks, one in the Territory and one in Western Australia not far from Turkey Creek. And there were two shootings, you see, both white men shooting blackfellers. It 
happened to be a police party this time, somewhere around 1890 just when the telegraph line was completed. Some white man did not like this shooting and he reported it down south through the telegraph, sent a wire down. There were white policemen and police boys, they generally had two or three, and sixty people were shot. They were on a chain but not taken into Wyndham jail. You see, they were making money out of the Aboriginal people, getting two shillings and sixpence a head at that time to feed the prisoners. And when they got a telegram to let the Aborigines go and to get the right man who killed a bullock - you see, every Aboriginal could not be all cattle killers - instead of letting them go that is what happened. They took them off to this particular creek and I think that is how it got its name Mistake Creek, through that. Well of course when they received a telegram to let the Aborigines go they had made a mistake arresting them and putting them on a chain, and instead of letting them go they shot them and burnt them. You will not see that in the newspaper, not like with the story of the Wyndham massacre.

In 1950 I finished up there and went into Wyndham. Next I got a job out here at Argyle repairing the yard and then $I$ went over to Newry station in the Northern Territory. In those days ro priest was up here. They all came after World War Two. They were not here much in 1950 but they poured in in 1960. There were all station people, no missions, and only one welfare station at Moola Bulla thirteen miles out of Hall's Creek. It used to be pretty bad, Moola Bulla, in those days, the time I had a row with the superintendent. It was somewhere around 1956 when they sold the place and let the Aborigines go. It is owned by a company now.'

I came back in '52 and got a job with the Main Roads Department at Wyndham. I worked with them from 1952 to 1956 and in that year I got a job with the Public Works Department laying water pipes for the Wyndham water supply, in from the pumping station. I was put on as a leading hand and a fitter and tumer but I did not stay there for too long. I left in 1957 because I was not given a fair go. One reason I pulled out was I was not getting enough money. I had to put the sockets in the asbestos pipes and test them myself. The engineer came up from Derby and I showed him a lot of faults in them and he gave me the job to test them. I was doing two other men's work. After leaving them I went to Hall's Creek and worked for the Main Roads from ' 58 to ' 59 , and in mid-1959 I went to Alice Springs and lived over there. I had a job there with a contractor putting down curbs and guttering in the streets, forming the road up and things like that, both me and my boy. We worked there, and in ' 61 we came back here to Kununurra and have been living here ever since. I never lived in the bush, only out on the stations. They had just started building the diversion dam in that year, had never even poured the cement. I was there when they poured the first cement in, and I think they finished it in 1963. I came up to Kununurra on the strength of that job, working on the dam. We camped down at Lily Creek then shifted to another camp in 1967. Then while I was in the hospital in Darwin the welfare put my second wife and two grandchildren on the reserve and gave them a house there. Of course, she flew up to see me and $I$ said: 'Well I'll be out, as soon as we get out. You stay in the house until I come there'. There were not too many natives there then. So when I came back we packed up the same day - I had a van - and we shifted to a camp. I left the reserve because they had no right to send my wife there. Before I went to hospital the welfare came out to see whether I wanted a house and when I told them I needed one I distinctly said that I would not live on the reserve under any consideration because the name reserve itself is discrimination. 'You're a fool', I was told, but I said: 'I'm not a fool. I'm a fool to stay there. I don't want you to push me around and stand over me'. It was a principle. 'I never was brought up in the native camp', I said, 'an you want to push me back in the native camp'. That was why I left the reserve.

? Moola Bulla government station was founded in 1910 , followed by Violet Valley adjoining it a year later (Biskup 1973:100). 
Before I got my pension I was working all the time here and there. During the wet we used to camp out, like we do now, when everybody knocked off station work in September. In those days they did not require any more labourers in September, not like today. Now I am retired on an invalid pension. I do nothing here, only fixing cars for different blokes who come in. Sometimes they pay me, sometimes they do not. I am making no money from repairing motor cars and helping people because they are broke too. My son in the town comes and goes. I chose to live here because my granddaughter was going to school here and my boy had a good job in Wyndham as a waterside worker. I planned once to start a garage, but I never finished it because I could not do it on my own. That is the only thing I regret, not being able to start a store, a bit of an agency. If I had money I would go to no-one. I am independent.

It is pretty good here. The only trouble is the pub and the arguments there when something is said about coloured people. I never stayed in one place when I was working. I did not like Wyndham. Kununurra was a better place to live although some people here are biased against the native people, including half castes. I am classed as a white man and those years ago I had my Citizenship rights. There was nowhere else to go. Hall's Creek was too far and Wyndham did not suit me. What I did not like was not having a house. My shanty would be blown down during the rain.

Today I do not think they have any objection when an Aboriginal girl marries a white man. You know, they are not like some of the Europeans who say: 'Look, what a black bastard doin with that white woman there?'. That is what they would say, but the Aborigines would not say that. It is only one way. It can happen the other way in Darwin, and there you see white women adopting black kids, you see a lot of that. I think it is so different because the Northern Territory is run by the Commonwealth government. The State government has its own laws and governs its own State. I think that has a lot to do with it. One time out in the back country you only wanted to say something out of place and look out, they would kill that dark man. That was the local law in these little towns in the outback. Oh that feeling is still hanging on here. There is a lot of colour bar still, a lot of class discrimination. It is different in a big town like Darwin. There is no colour-bar over there; ${ }^{8}$ different altogether. I do not know why. In the early days in the Territory they treated the Aborigines the same as here, but after the World War Two they went up pretty quickly, and sort of changed the law then. That did not happen here after the war, only lately. I know way back in the 'fifties there were a couple of white men in Wyndham who did not like their kids to go to the State school there with the Aboriginal people. Before that the Aboriginal pcople, or part-Aborigines were not allowed to go to school in Wyndham. Did you know that?

Native Welfare has been changed to Community Welfare, but that is no different. They are still Native Welfare. They are not the same, never ever changed, and should not be combined. You go to the court, say. A lot of the time the Aborigines do not get justice because the community welfare believe the policeman. Sometimes the policeman can be wrong. In a lot of cases when they make the charge the welfare do not look into it deeply and do not quite understand. They should have some Aboriginal people there to see that they do get justice. And it is not only fullbloods, they do that to the poor white man too. He gets no justice here, never. The local J.P.s are no good. Kununurra is full of them. They work with the crowd. There is a clique here you see - the farmers and the squatters and the missionaries, they are all one. Well, they are not so mixing with the missionaries, but say the businessmen. It is better if the people are tried by a magistrate as is done with most of the court cases in Darwin. Here there is a travelling magistrate. However, I do not think you would find Aborigines here clever enough to go in and help the others. You want a bit of education to do that, and you want to understand what you are talking about.

This is one of the folk myths of the north. It is extremely unlikely that Darwin is subjectively very different from other European northern settlements where race relations are concerned. 
And with the kids going to school, well one of the missionaries, the Catholic, is involved in that. Why do they have to do that? Why do they have to interfere with the Aboriginal people? You see, they should not interfere with somebody else's kids. One time here all the welfare were Catholic and when they were tried in the court they took the kids off them and sent them away to a Catholic school. Why is that? That should not be. The parents should have the say: "No, my kid not goin there. I wantim to go to such-an-such a place'. A lot of the parents do not get the freedom to say that. The freedom is taken away when the child is taken to court and it becomes a court case. Well, parents should be able to object and say: My kid is not goin to your religion'. It still happens now. I think a lot of people, some of them, are frightened to say these things. I do not think it is an accident. There is a lot of that going on here in Kununurra. They keep them down by changing them. Their religion is no good. If parents object they should not do that. If the welfare decided to send a child to a Catholic school that should not happen. The government should take over and send them to their school, or to a school where the parents want them to go. I have no religion, but as I said before I believe the native custom and I follow that. I will not accept Christianity. Christianity is the ruination of the Aboriginal people. They do not educate the kids. They are not kept longer at school. The church and school have done nothing for the natives.

And the welfare were on their back all the time and did nothing for the natives. They wanted to be master all the time. They did not go and ask the native what he wanted but told him what he wanted. This was in the past but it is still not good. The Aborigines cannot vote and that is the point. The welfare do not do anything about it, that is their policy. They have never explained what voting means to the native. A lot of these Acts which are about bother me. I would like to see the Declaration of Human Rights. I read in the paper one time that Section 18 of the Liquor Act says that a publican has no right whatsoever to ask people questions; he is there to serve refreshment to anybody, it does not matter who, and the penalty for not doing so is fifty dollars. ${ }^{9}$ A lot of them do not serve Aborigines. Now, my brother went up with Tom Wilson the squatter and he got a station in the Hall's Creek area. He knew him for twenty-five years and what happened? The publican went over and told Wilson: 'E's not allowed in the pub. E got to drink out, e can't be brought ere, e got to get out'. Well that is his colour bar, his discrimination, and that is bad. My brother was net being noisy or anything: he just went in there. I have been here since 1961 and there has been a lot of discrimination in the pub by the publican, the owner. That is going to cause trouble here. You go to Wyndham now, there is no discrimination in those pubs. They can drink and do what they like. If they are too drunk the police have to tell them to go home. Well here they used to ring up and get the police and of course when they start slinging dirt that is where the discrimination comes in. Naturally, when the publican gets knocked over that is his own fault. Not long ago he was knocked over and I believe that the bloke who knocked him got eighteen months. That was bad, you see.

That native boy came here from Darwin. He was a Wyndham boy but he had been away in Sydney for a long time. He came down here for help but we would not give it to him. He said to me: 'You come up to the pub?'. 'What for?', I said. He replied: 'To stand by. We got to get into the publican'. He was sticking up for another man, was going to go there and cause trouble over one person. 'Not on your life', I said, 'I'm not going up there'. He then said to my boy: 'What about you? Are you comin

9 This appears to be in fact Section 118 'Penalty for refusing entertainment' which reads, in subsection (1) 'Any holder of a publican's general license, a limited hotel license, or a waysidehouse license, or an Australian wine, beer and spipits license, who, without reasonable cause, refuses to receive any person as a guest in his house, or to supply any person with food, liquor, refreshment or lodging, commits an offence against this Act'. The penalty was $\$ 100$. (Western Australia Licensing Act 1911-1965). 


\section{THEY DID IT THEMSELVES}

up ere?'. 'Look Norman', Alan said, 'I went to school with some of these white people up ere in Wyndham. I lived ere in Kununurra an I'm well-known ere. I don't want to cause no trouble in the pub. So leave me out of it'. And I said to this Aboriginal: 'You see, you'll find yourself in jail tomorrow. You cannot do that'. That young feller from Sydney was trying to have the Black Power movement here you see. It started this year a month or two ago I think. That was the time they knocked the publican down. That feller was trying to cause trouble in Darwin but the Aboriginal people there would not take any notice of him, they just ignored him. He was trying to cross up, and he was trying to cause it here. I would not know what happened to him. He was no good, see, with that in his head. And there was this half caste boy who came over with that fullblood Aboriginal. He disappeared. He was on a drunken driving charge over the same incident they had here with the publican. He was no good. There was a story that a big mob were going to come from Wyndham, but nobody came. When they asked him he said there was a big mob at Fork Creek. Well all I know is there are all pensioners at Fork Creek. They would not come out here and do anything like that. $A$ lot of them are friends and relatives of people here. I told him: 'You don't know what you're talking about. You gotta go home an go back to Wyndham. Otherwise you'll find yourself inside'. That rumour made everybody frightened, but I stayed here. I never went bush like a lot of the others. Well if they were going to kill people they would have followed us out there and killed us just the same. I believe the white people, every one, had the shits properly. They were buying rifles and taking off to the police station to get them registered, in Wyndham and here. I know there was one couple who took a rifle up there. Any other time you go to buy a rifle here the police will not give you a license, but this particular day they gave them rifles and a license to carry firearms. Those kinds of things are wrong; they are looking for trouble. ${ }^{10}$

Work here now is better only for some people. Some are victimised from getting a job up here - fullblood, half castes and some of the whites - any job. They cannot get jobs now. I do not know what is going to happen in a couple of years time when all the young Aborigines come back from school and cannot get jobs. Since World War Two everything was going well and smooth and they started paying the Aborigines wages. Some of the stations still treat them badly by not giving the full basic wage. There was some talk of Rosewood, that a stockman from a kid up got $\$ 26$ instead of $\$ 42-45$ a week. But now we have more welfare than Aborigines. Most of the young people today you see here were all bred up after World War Two. It has become worse and worse. They will not do the work. You see, they go over there for a feed, get everything out of the pensioners. The pensioners should be separated from the younger people who go and get the money off them, drink it up, and come back for a feed and eat them out. They have no tucker. It is getting worse because young people now are telling each other: 'Why do you want to work? Why don't you be like me, going around? I don't have to work. I go over there and get a feed'. I know a lot of people who have been here for years and they will not go to work when they are supposed to. You see them in a group. You see them go to a camp and squat down there and then eat everything in the camp. But they are not lazy. The only reason why they behave like that is through the grog. One time you never saw this, anything like it. The Aborigines in those earlier days behaved better. Getting too much grog now is the main trouble with them. They never used to go round and

10 In Oct. 1973 there was a Black Power scare in the town which lasted a couple of days. Sandy's version is substantially close to that of many other rumours which were flying at the time among both Aborigines and whites. Perhaps more than anything else in my fieldwork, it underlined the truly abysmal gap of understanding between the two cultures. There were overreactions on both sides, the strongest element being one of fear. I heard stories of 'neurotic' European housewives locking themselves in their homes with rifles and shotguns. I witnessed at first hand the panic among Aborigines on the reserve. 
buy gin and go to somebody else's camp and do what they liked. They used to obey the Law, but not today.

The only thing I can see is that people born in the country did not want to leave, but some could not get jobs, both Aborigines, some whites and part-Aborigines. Newcomers arrive and they put them on, and when it gets hot they go away down south. Some come to make money and just to travel around Australia, not live here. That is why a lot of Aborigines are out of work. And they cannot save money. They put money in the bank today in the morning and in the evening some of them go back and draw it out. I never had enough to save and I am on a pension now. When it was in the good old time the wages were very low, only two pound threepence a week. We used to camp eight months in the year waiting for a job. Only working six months in a year, how could we support ourselves on that? Six months, the dry season, was the working season and eight months was the wet. It was a long time, and sometimes we used to start late. Sometimes the wet was for six months, shorter. Most stations generally knocked off in August, not like today when they are still working. One time they did not do that. They had good men, experienced on the stations who used to go round the run twice in a year. Now this time they have a job to go round once, to brand the calves. They work on the stations for longer now, and they started late too owing to the big wet this year. Any other year a lot of people used to work right up to September. When I worked on Rosewood - Kilfoyle owned the station that time, used to manage his own station - we worked from March till August, finishing at the end of August, and there were no more jobs.

In the old citizen right days when they used to sell this beer ticket to Aboriginal people for two dollars, they used to get the man with the beer ticket to buy the grog on the quiet and take it down to the creek where nobody could see, and they would all get together. Around the pub the native people were not popular without a beer ticket, the rights book. It was a disgrace for the Australian citizen to carry that. The Citizenship right was discrimination. In the Northern Territory it was different. Everybody was the same, all classed as Australian eitizens. They could walk into any pub and were not asked for a beer ticket. In the past, fullbloods were not allowed to drink with white people. That is why we have a lot of drunken natives in the country. I think that was bad for the Aborigines. They have kept on doing that. And they were forcing young boys, even school kids for a few bob, to buy grog. They drank quickly for being gluttons and did not want to try to keep sober. You hear them talking: 'I got drunk last night. I had so many bottles of beer. I had a bottle or flagon', and all that. That is not right. And even the kids are going around drinking. The parents teach them. Why does the publican keep on serving them with liquor when he knows they are drunk? That is where the welfare should step in and do something, and the police should be given stricter law. These sorts of things in the long run cause trouble.

Sometimes I have a beer. The doctor told me I must have one now and again, but I do not drink heavily, no. I do not know why people drink heavily. It may be the way they were brought up, to just go in there and do what they like. You get a lot of blokes in the pub will not leave it. That is how it happens, they drink too young. There are a lot of young people here drinking and some are not eighteen. What is wrong with the law? They just need to go round and ask their ages. Some of those drunk people are born around here; others come from Port Keats. There are Malngin and Ngarinman people here, and some Gidja ones who drink. There are a few at Lily Creek. A lot of the young coloured boys there do not want to go to work. Welfare should send people like that away and see that they get work or something, that somebody teaches them something. They could put in someone, a man to go around and educate them. I think they drink just for being ignorant; they do not know any better. You see, when an Aboriginal person goes to the pub he goes not to just have a drink but to get drunk, to get a big quantity of grog. He does not want to drink like 
a European - go in and have a few glasses of beer and take a bottle with him and walk out - he wants to keep on drinking. See, they keep on drinking and drinking. You see how many native women go in and out of hospital here with eracks on the head and broken arms. The old men on the reserve are frightened.

With the workers the Aboriginal people are all together, one, and some of the foremen, but not with the local government body (Shire Council members) regarding native rights. Workers and natives get on well but local government people have kept the native people down all the time, stations and missions, you can't get away from that. To them, the natives are third class citizens. In the past just going back two years the poor man did not get justice. If a rich man gave a drink to an Aboriginal he was let off with a warning and some patrolmen did nothing about it. That was in the past. They have a good policeman this year. There is a bit of class distinction I suppose between some of the new Australians, and between natives and partnatives. Some part-Aborigines look down on the fullbloods, but not all. In my opinion Kununurra is a moneyed man's town. What all the fullblood Aborigines and part-natives do not like is using two laws on human beings, one for the poor and one for the rich. At Timber Creek over the border one policeman controlled everything and there was no trouble. There was a difference between Kununurra and the Territory. There was no trouble in the Territory since the Aborigines were given drinking rights, no-one in jail. Before that, whites could go to jail for supplying and the native for receiving. To some people drinking is terrible, not to all but to mostly fullblood women. A lot were out of work and would not take a job because they were on the grog. And some whites gave women grog to make them drunk, just to get the use of them. There should be someone here to look after these drunken people.

I think the government has misunderstood badly about Aborigines. Take living in groups. You know that in the old native custom every Aboriginal hunted for himself, camped for himself and lived by himself. They had little wurlies, not bumped up in a heap like they do up here. There was none of that in the old native custom days. You would see one with a little mia-mia over there and another one over there, and another one over there; not all in a group. They had plenty of space between them. It is the welfare idea to build one house and put all the natives in there. They started that by building a big bungalow and putting everybody in. You could have about twenty-four people living in one house. A lot of the natives did not like to go in there but they were forced to and they accepted it. They were told to get in and they went because they were frightened of the big-feller boss. Living in groups started with the stations. The Aborigines camped in the bush had to hunt for their tucker every day. They did it themselves. They would go out and get a kangaroo and when they brought it back they shared it out - you never saw a man starving, that was one thing. But the way the government works it now with the group of Aborigines starting a garden, I do not think it will ever happen, not here, if you want a group to go in with you. It is the same with me. I said to a bloke from Canberra: 'You gonna have trouble with the group of Aborigines here'. If it was individual it would work better. The man would grow the garden and he would know when he sold the produce he would get money. The way it is, he is growing a garden for somebody else and not getting paid. To prove that they could do it here they should have said to one man: 'You start your garden here, you start your garden there. I'll show you how to grow every thing'. The time to teach them would be after the wet because you put the seeds in somewhere around January: 'You grow your own vegetables there. Anything you sell out of that is yours, not that feller's'. I think that would work.

You want to go to Wave Hill for a weekend and have a look around. They get on well there as far as I know. They built a town area for the Aboriginal people, a native welfare settlement and a police station. And then there were the native people 
at Wattie Creek. They refused to go there, choosing to stop in their tribal land. They had houses put up and an overhead tank with water laid on. Everyone's tent or bit of a hut had a garden. Why have they never had it here? And white people went there voluntarily to help those people, and some of them are still there. They did not say: 'We don't want a white man to tell us what to do'. Now if I had to start farming I would go to the agriculture mob to get information to show me how to grow things. Some of the farmers here get advice from them. That is what they wanted here. On Wave Hill they still believe in the native custom, but it is breaking down here. That is terrible. The old people are not trying. And say with the garden, a man over there said that the old fellows were over their heads and bossing people around, telling them what to do. The first thing he said was: 'T'm not going t' grow vegetable for em. Bugger em, sitting down over there givin orders'. It will not work with the Aborigines as a group. If they had their own property, individually, and were paid wages they would work. They will not work voluntarily.

You have to have somebody to put you on your feet. Say, if you put an uneducated man on to books he would not know where to start or what to do. It is the same thing. You have to teach people, to show them. Europeans should have started the garden for them and showed them how to grow those things. That is one thing about Wave Hill, the Aboriginal people there never said 'we do not want a white man to show us what to do'. They knew in their own hearts that they wanted somebody to help them, and they got help. One of the fullblood boys around here said to me: 'We don't want a white man to tell us what to do'. 'Well what can you do', I said, 'You can't do nothing'.

Way back I tried to organize things and said to one or two half castes (not fullbloods), that we should all get together and start a business. 'Who's gonna handle the business?', they said. 'One man have to handle the business', I replied. 'Oh', they said, 'that won't work with us'. 'Why?'. 'You'Il run away with the money'. 'You can't run away with the money', I said, 'When you get these things you registered, and agreement drawn up by a Justice of the Peace or police or welfare. How can you get away with it? You raise it as a company, you cannot get away with it'. So one reason they do not work together as a group is that they distrust each other. They point out a leader, the Aborigines today, and say that he owns the place because he is a leader of the gang. They do not understand the company affair, not like Europeans who form a company and put a manager there to run it. They do not quite understand that. A lot of part-natives do not understand too. It all depends where he went to school and how he was taught. Working in a group can work if they understand. But it is better to do it yourself. What the government should have done when they started out was to start the Aborigines on a little farm, a garden block here and there, and see how they go instead of spending a few thousand dollars trying to get the group to do the work there. If you work on your own, well, you know you have a place that is yours. If you worked for them you had to pay them. Living and working on your own as I said last time is the old way in the Law. The Aboriginal used to camp on his own and go out and hunt on his own. When they brought a kangaroo or emu or anything to the camp they always shared the food amongst one another because they could not eat it all themselves before it went rotten. But even the idea of sharing does not work properly in a group like this. They are just too busy I think.

Some of the pensioners over there should not be leaders because they are out of date. There should be somebody with a bit of intelligence and education to be a leader there, but most of them with a bit of education cannot leave the pub. Some of the leaders we have here were not good enough either, two here and a couple of boys from Wyndham. They did not have the education for a start - I think that is the main trouble - and they do not think about what they are doing. They did not think before they talked; they were not quite awake. For a start, they said they were 


\section{THEY DID IT THEMSELVES}

going to knock down all the ground here and told us: 'You gotta shift from ere. We gonna build the houses here right down there, an put down streets an roads an things like that'. They had that in their minds you see. I said: 'What about the government, the Shire Council, did they give you o.k. to do this?'. They said: 'Oh, we get it from Canberra'. I said: 'Canberra can only grant you money. This is State of Western Australia. They govern their own State'. ${ }^{1}$

Stock work is something a group does better. That would be different. But I do not know about letting the council have Argyle and a chance to prove themselves that way. These fellers here have been too long in the pub. They would be running in and out from Argyle chasing grog. I cannot see how they would make a go of it without a European or a part-European there to see and run the place. It is very hard to get a part-European here to go out there. If you are a manager on a place well you have to look after it, you should not neglect it. Durack had good men for years. There were only a few boys at Rosewood with Kilfoyle and no younger boys are living now; they are all old, sort of dead. They would have understood better, those who went out to muster cattle for the meat works. When I worked on Newry a bloke by the name of Hector Fuller was managing the station, but he never left the verandah. He used to send the boys to go out and muster and brand up the calves and get the bullocks, saying to one boy: 'You go out an get five hundred bullocks. Get more if you can'. Well they went out and brought them in. Those boys had that experience you see. Tiger was one. He worked for Fuller a long time and used to be a smart man that feller. Well nobody is there now. Bulla was a good man. He worked on Argyle a lot and was brought up under good men. He might go ahead. ${ }^{12}$ But not some of the

11 This was the Kununurra Aboriginal Progress Association, established around July, 1974 by a relatively 'militant' group within the part-Aboriginal community as a response to, and in competition with, the fullblood Mirima Council, itself formed a little more than two years carlier in September 1971. The members of the Association identified more closely with the European community, shared many of its values, paradoxically harboured strong (and justifiable) resentments against whites ("The Aboriginal people have been kept down'). Some of its members revealed scarcely-concealed contempt for the alleged naivet $t$ of the fullbloods. The Association's chief goal was the improvement of living canditions for its members by building a village on land in the north-west comer of the town's boundary, where several camps had stood for some years. In their endeavour to lever the government authorities into allowing this, they began building a shed on part of the land. This was the project mentioned by Sandy. They used money siphoned off from the Mirima Council's funds, according to members of that Council, on the principle that it came under the aegis of the Association, which purportedly spoke for all Aborigines in the town. The money ran out and the frame of the building stands unfinished to this day. The Association was refused the land on the ground that aerial spraying of pesticides on an adjacent stretch of farmland was a health hazard. White authorities appear to have been unconcerned over the health hazard earlier. The Hooker company which was using the land moved olt of the district in the following year. Finally, the leadership of the Association succeeded in alienating itself not only from Europeans and the Mirima Council but also from its own members. One man was virtually its driving force. He and another, backed by a European adviser/convenor, froze out a keen core of members from committee activities when it appeared that his name was not on any of the sub-committees they were forming. This was the tragedy of the Association. It may have come to something, but its leadership was out of touch with its members. When that one man opted out from a combination of frustrations and personal troubles it produced the collapse of the whole structure.

12 Bulla Bilingiin was a member of the Mirima Council who made a request for land of outstation size in the Dingo Range area in 1975, and early in 1977 this became a reality. He has the land, vested in the West Australian Aboriginal Lands Trust, on a lease-hold for eighteen years, and a small cluster of families live there much of the time, commuting frequently to the town to visit relatives. This change makes Sandy's suggestion a reality for a time, although the issue that this and other land should be freehold granted in perpetuity to groups such as Bulla's, is the chief concern of those advocating Aboriginal rights through compensation. At present it appears too easy for retroactive legislation to remove tomorrow what was given today. There are various examples in the history of race relations in Western Australia. Biskup 
others. They have no idea. They cannot control the reserve. They do understand their own Law and its rights and wrongs, but the things they do now they would not do if they stuck to their own Law.

What I think myself, if the government put up a non-Christian settlement out of town with the elders there and someone who understands the Aboriginal language to run the place, I think you would find out a lot by doing that. You would find out the difference, the old way and customs, how they used to carry on years ago. I heard news from Canberra that the government was going to preserve the Aboriginal identity, their language and culture, and their way of life and their beliefs. Well they cannot do it here. It is dying out here. I think that is the only way to find out whether the Aboriginal is going to pull himself together, separate the elders from these no-hopers here and bring them in from way back. The elders they have here I do not think know anything either about the white feller or about Aboriginal culture. They are not too old and they were all the time working on the stations. Some remark passed by one, somebody told me yesterday, showed that he did not understand, did not believe Aboriginal culture, and he is an Aboriginal himself. What he said was that he did not believe it. Maybe he wants to go over to the white man's ways. He knows what he is talking about and I do not think he believes Aboriginal custom, otherwise they would have better control over there.

The change I would like to see is the white people to put the Aborigines on their feet. You see, white men can help to show them how to work these things, how to grow anything or run a cattle station, show them right from wrong and get them on their feet. Fullbloods do not quite understand here because they have never been taught. Teach them that you cannot go in and drink in the pub every day right up to half past eleven and go home, burning petrol and chucking your money away giving it to the publican. That is wrong. Between natives and the people living in the town you should have a better understanding. It is the people who run the town are doing the discriminatory things, like in the pub. It would be good if they had something here like a technical school, but it would have to be run by a native to see that the work is done. That would be handy. The welfare department has nothing to prove, not in the Kimberleys.

I am just an ordinary man, born to do work. At present the most important thing in my life is to have a bit of a place of my own where I can grow vegetables and live decently. I cannot do hard work now: I am buggered up, I get short-winded. One time I used to go out and cut somewhere round sixty posts before dinner. I cannot now. If I had a garden and was receiving a pension that would be good. I used to save a bit, even on a pension, twenty dollars a fortnight. We have that sometimes and sometimes we do not. I did not chuck my money away foolishly. I intended to start a market garden about four or five years ago and I still plan to do something. This law they have about granting money to a group of Aborigines is why a lot of people do not go into it. If they granted more money to individuals - long term loans there would be a lot of that and they might make it a success, because they will be working for themselves. They might change you see. As I told you in the background, a lot of the Aboriginal people do not have it in them, to wake up.

DARWIN COMMUNITY COLLEGE AND KUNUNURRA, W.A.

(1973:144) notes that the 1907 Electoral Act disenfranchised all Aborigines in the State, and it was not until 1971 that voting rights were again extended to Aborigines in the Pilbara and the Kimberleys. A Kimberiey Land Council letter dated 4 August 1978 notes that 'The Westem Australian government is proceeding to amend the regulations governing the Aboriginal Affairs Planning Authority Act to deprive Aboriginal communities of the right to say who may enter onto their reserves... . This is being done in the wake of a sudden upsurge of interest in Aboriginal reserve lands among mining companies'. 


\section{BIBLIOGRAPHY}

Biskup, Peter. Not slowes not citizens. St. Lucia, 1973.

Gjessing, Gutorm. 'The social responsibility of the social scientist', Current Anthropology, 9 (5), 1968:\$97402.

Kettle, Ellen. Gone bush. Sydney, 1967.

Shaw, Bruce. Social relations and commitments in a planned new town in Western Australia. Ph.D. thesis, Department of Anthropology, University of Western Australia, 1974.

Stevens, Frank. Aborigines in the Northern Territory cattle industry. Canberra, 1974.

Willis, William Jr. 'Skeletons in the anthropological closet', in Hymes, Dell ed. Reinventing anthropology. New York, 1966:121-152.

\section{AUSTRALIA 1788-1988: A BICENTENNIAL HISTORY}

A number of historians and other social scientists have embarked on a co-operative project intended to mark the bicentenary of European settlement in Australia. F.K. Crowley, Professor of History at the University of New South Wales, is to be general editor of four reference volumes: a volume of historical statistics; a historical geography; a guide to sources; and a handbook, encyclopedia or manual of Australian history. K.S. Inglis, Professor of History in the Research School of Social Sciences, Australian National University, is to be general editor of a series of volumes on Australia to 1788, Australia in 1838, Australia in 1888, Australia in 1938, and Australia 1939-88. Enquiries and offers will be welcomed by the general editors and the volume convenors:

Australia to 1788: Professor G.N. Blainey, Department of History, University of Melbourne; Professor D.J. Mulvaney, Department of Prehistory and Anthropology, Faculty of Arts, Australian National University.

Australia in 1838: Dr A.T. Atkinson, Department of History, University of Western Australia.

Australia in 1888: Professor J.W. McCarty, Department of Economic History, Monash University; Dr G. Davison, Department of History, University of Melbourne; Dr J M. Powell, Department of Geography, Monash University.

Australia in 1938: Dr W.L. Gammage, Department of History, University of Adelaide; Dr P. Spearritt, School of History, Philosophy and Politics, Macquarie University.

Australia 1939-88: Dr A.W. Martin, Department of History, Research School of Social Sciences, Australian National University. 